Received Date: 15-Dec-2014

Revision Requested: 6 Feb-2015

Revised Date : 20-Feb-2015

Accepted Date: 18-Mar-2015

Article type : Regular Paper

\title{
Acetylcholine contributes to control the physiological inflammatory response during the peri-implantation period
}

\author{
Daniel Paparini ${ }^{1}$, Soledad Gori ${ }^{2}$, Esteban Grasso ${ }^{1}$, Walter Scordo ${ }^{3}$, Guillermina Calo ${ }^{1}$, \\ Claudia Pérez Leirós ${ }^{1}$, Rosanna Ramhorst ${ }^{1^{\star}}$ and Gabriela Salamone ${ }^{2^{*}}$
}

* Both Senior authors contribute equally to this work

\author{
${ }^{1}$ Departamento de Química Biológica, Facultad de Ciencias Exactas y Naturales, \\ Universidad de Buenos Aires. IQUIBICEN-CONICET. ${ }^{2}$ Instituto de Medicina Experimental- \\ IMEX-CONICET, Academia Nacional de Medicina. Buenos Aires. \\ ${ }^{3}$ Servicio de Medicina Transfusional, Hospital Italiano de Buenos Aires, Argentina
}

Running title: Acetylcholine at the maternal-placental interface

\section{Corresponding author:}

Rosanna Ramhorst Ph.D

Laboratory of Immunopharmacology

School of Sciences, University of Buenos Aires

Int. Guiraldes N 2160

Ciudad Universitaria, Pabellón 2 Piso 4.

(C1428EHA) Buenos Aires, Argentina

This article has been accepted for publication and undergone full peer review but has not been through the copyediting, typesetting, pagination and proofreading process which may lead to differences between this version and the Version of Record. Please cite this article as an 'Accepted Article', doi: 10.1111/apha.12494

This article is protected by copyright. All rights reserved. 
$F A X:+54-11-4576-3342$

e-mail: rramhorst@qb.fcen.uba.ar

\begin{abstract}
Maternal antigen presenting cells attracted to the pregnant uterus interact with trophoblast cells and modulate their functional profile to favor immunosuppressant responses. Non neuronal cholinergic system is expressed in human cytotrophoblast cells and in immune cells with homeostatic regulatory functions.
\end{abstract}

Aim: The aim of this work was to evaluate whether non neuronal acetylcholine conditions maternal monocyte and DC migration and activation profiles.

Methods: We used an in vitro model resembling maternal-placental interface represented by the co-culture of human trophoblast cells (Swan-71 cell line) and monocytes or DC cells.

Results: When cytotrophoblast cells were treated with neostigmine (Neo) to concentrate endogenous acetylcholine levels, monocyte migration was increased. In parallel, high levels of IL-10 and decreased levels of TNF- $\alpha$ were observed upon interaction of maternal monocytes with trophoblast cells. This effect was synergized by Neo and was prevented by atropine, a muscarinic acetylcholine receptor antagonist. Similarly, trophoblast cells increased the migration of DC independently of Neo treatment, however enhanced IL-10 and MCP-1 synthesis in trophoblast-DC co-cultures with no changes in TNF- $\alpha$ and IL-6 was observed. In fact, there were no changes in HLA-DR, CD86 or CD83 expression. Finally, trophoblast cells treated with Neo increased the expression of two antigen presenting cellattracting chemokines, MCP-1, MIP-1 $\alpha$ and RANTES through muscarinic receptors and it was prevented by atropine. Conclusions: Our present results support a novel role of acetylcholine synthesized by trophoblast cells to modulate antigen presenting cell migration and activation favoring an immunosuppressant profile that contributes to immune homeostasis maintenance at the maternal-fetal interface.

This article is protected by copyright. All rights reserved. 
Keywords. Dendritic cells - Non neuronal acetylcholine - Monocytes - Trophoblast cells

\section{Introduction}

Pregnancy involves different immunological stages with a pro-inflammatory or antiinflammatory predominant profile depending on the stage of gestation analyzed (Mor 2008; Dekel et al 2010). A successful implantation occurs in a regulated pro-inflammatory microenvironment that allows tissue remodeling and angiogenesis at the maternal-placental interface. After implantation, the predominant pro-inflammatory microenvironment is modulated to an anti-inflammatory/tolerogenic profile required for fetal growth (Mor and Cardenas 2010).

The control of the pro/anti-inflammatory microenvironment implies several regulatory and tolerogenic circuits at the site of fetal antigen exposure, that might operate all coordinated to sustain gestation (Aluvihare et al 2005; Terness et al 2007; Blois et al 2007; Leber et al 2010). In this sense, trophoblast cells coordinate the selective recruitment of maternal immune cells, such as antigen presenting cells (Huang et al 2008; Fraccaroli et al 2009a; Fraccaroli et al 2009b; Gomez-Lopez et al 2010; Dekel et al 2010; Harris LK. 2011).

Particularly, decidual macrophages and dendritic cells (DC), are recruited toward the fetomaternal interface following a chemokine gradient where they are conditioned by trophoblast cells to express an anti-inflammatroy profile contributing to immune homeostasis maintenance through immunosuppressant cytokine synthesis (Laskarin et al 2007; Plaks et al 2008; Dekel et al 2010). In fact, human DC upon interaction with first trimester trophoblast cells were able to increase the frequency of CD4+CD25+Foxp3 cells with suppressor ability (Salamone et al 2012). Regarding human maternal monocytes, they are recruited to the decidua and differentiate to macrophages with a predominant 'alternative' activation profile characterized by the clearance of apoptotic cells and the release of immunosuppressant mediators (Abrahams et al 2004; Renaud et al 2008; Nagamatsu and Schust 2010). DC and macrophage functional plasticity is modulated by cytokines, chemokines and This article is protected by copyright. All rights reserved. 
neurotransmitters through autocrine and paracrine circuits under the control of trophoblast cells (Abrahams et al 2004; Mor 2006; Fest et al 2007; Renaud et al 2008; Nagamatsu and Schust 2010; Harris LK. 2011; Pérez Leirós and Ramhorst 2013; Grasso et al 2014).

Regarding the neurotransmitters, non neuronal acetylcholine (ACh) is synthesized and released mainly by cytotrophoblast cells of human placenta where it regulates placental blood flow, facilitates amino acid transport and hormone release (Olubadewo and Rama Sastry 1978; Bhuiyan et al 2006; Wessler and Kirkpatrick 2008; Grando et al 2012; Wessler et al 2012).

Previous data have shown that macrophages express choline acetyltransferase (ChAT) and synthesize ACh which inhibits the production of pro-inflammatory cytokines (Borovikova et al 2000; Wessler and Kirkpatrick 2008). Likewise, human DC express M3, M4 and M5 muscarinic ACh receptors (mAChRs), ChAT and acetylcholinesterase (AChE), and both ACh and the acetylcholine mimetic drug carbachol modulate DC activation and cytokine production (Salamone et al 2011). However, the role of ACh as a modulator of the maternal immune response during pregnancy is unknown.

Taking into account that trophoblast cells condition the profile of the antigen presenting cells and ACh can modulate their cytokine production, here we investigated whether ACh produced by trophoblast cells conditions the migration and activation profile of antigen presenting cells. For that purpose we used an in vitro model resembling maternal-placental interface represented by the co-culture of human trophoblast cells (Swan-71 cell line) and maternal monocytes or DC cells.

\section{Materials and Methods}

\section{Blood samples}

Blood samples were processed from healthy fertile women, defined as women who had two or more previous normal pregnancies without any miscarriage in their clinical records, nonsmokers, who were not under pharmacological treatment for at least 10 days before the day of sampling. Blood was obtained by puncture of the forearm vein, and it was drawn directly

This article is protected by copyright. All rights reserved. 
into heparin containing plastic tubes. Studies were approved by the "Academia Nacional de Medicina Review Board" and Ethical Committee. All healthy donors provided written informed consent for sample collection and subsequent analysis.

\section{Monocyte isolation and differentiation to dendritic cells}

Peripheral blood mononuclear cells (PBMC) were isolated from individual subjects and CD14+ cells separated by positive selection with CD14+ micromagnetic beads (Miltenyi Biotec., Bergisch Gladbach, Germany). Cell population purity (>95\%) was checked by fluorescent-activated cell sorting (FACS) analysis. DC were obtained from monocytes $\left(10^{6}\right.$ cells. $\mathrm{ml}^{-1}$ ) in the presence of $20 \mathrm{ng} \cdot \mathrm{ml}^{-1} \mathrm{IL}-4$ and $20 \mathrm{ng} \cdot \mathrm{ml}^{-1}$ GM-CSF for five days as described (Salamone et al 2011; Salamone et al 2012). Differentiated immature DC (>99\%) were checked by FACS analysis using anti-CD1a mAb.

\section{Co-cultures}

Trophoblast cells (Swan-71 cell line, derived by telomerase-mediated transformation of a 7week cytotrophoblast isolate (Aplin et al 2006; Straszewski-Chavez et al 2009), were kindly given by Dr Gil Mor (Yale University, New Haven, USA); cultured in 24-well flat-bottom polystyrene plates in complete DMEM:F12/10\% FCS (Life Technologies, Buenos Aires, Argentina) or with $2 \%$ FCS (DMEM $2 \%$ ) to prepare conditioned media. At $60 \%$ confluence, adherent trophoblast cells were cultured with DC or Mo $\left(5 \times 10^{5}\right.$ cells/well) as described previously (Salamone et al 2012) (in the presence or absence of $20 \mu \mathrm{M}$ Neo (acetylcholinesterase inhibitor) and $100 \mathrm{nM}$ atropine (AT) or $10 \mathrm{nM}$ carbachol (Carb) during $24 \mathrm{~h}$. Trophoblast cell viability was not affected in the presence of $20 \mu \mathrm{M}$ Neo. DC cocultures were performed in the presence of IL-4 and GM-CSF to maintain DC differentiated profile.

\section{Collection of trophoblast cells conditioned media}

Swan-71 cells were cultured in 24-well flat-bottom polystyrene plates in complete DMEM $2 \%$ FCS overnight to obtain conditioned media $(\mathrm{CM})$ in the absence or presence of $20 \mu \mathrm{M}$ neostigmine, $100 \mathrm{nM} \mathrm{AT}$ or $10 \mathrm{nM}$ Carb. To assess that adherent trophoblast cells were not

This article is protected by copyright. All rights reserved. 
removed during the $\mathrm{CM}$ collection procedure, RNA levels were determined and they were below the detection limit. $\mathrm{CM}$ were collected and were all stored at $-20^{\circ} \mathrm{C}$ until use.

\section{RT-PCR}

ChAT, AChE, muscarinic receptors (mAChR), and chemokines (MCP-1, MIP-1a and RANTES) expression was determined by RT-PCR as previously described (Fraccaroli et al 2009b; Salamone et al 2011). Briefly, total RNA was isolated (Life Technologies, Grand Island, NY, USA), reverse transcription performed (Clontech; Palo Alto, CA) and cDNA fragments amplified using $0.1 \mu \mathrm{M}$ of each primer (sense and antisense) (Table I) and $1 \mathrm{U}$ Taq polymerase in a DNA Thermocycler (PerkinElmer/Cetus, Boston, MA, USA). PCR products were fractioned on $2 \%$ ethidium bromide-stained agarose gels, visualized by transilumination and scanned. Densitometry was performed using ImageJ software (http://rsb.info.nih.gov/ij/) and results expressed as arbitrary units normalized to GAPDH expression.

\section{Flow cytometry analysis}

Cells were stained with the following mAbs: FITC- or PE-conjugated mAbs directed to CD1a, CD14, CD83, CD86, HLA-DR, TNF- $\alpha$ and IL-10. Ten thousand events were acquired in a FACS Calibur ${ }^{\circledR}$ cytometer and results were analyzed using WinMDI 2.9 software (http://facs.scripps.edu/software.html).

\section{Measurement of cytokine production}

DC were cultured or not with trophoblast cells in the presence of $20 \mu \mathrm{M}$ Neo and $100 \mathrm{nM}$ AT for $24 \mathrm{~h}$ at $37{ }^{\circ} \mathrm{C}$. As an additional control trophoblast cell secretion was quantified under basal conditions for each mediator. Then, culture supernatants were collected, centrifuged, and analyzed for the presence of TNF- $\alpha$, IL-6, IL-10 and MCP-1 by ELISA (e-Bioscience, Los Angeles, CA, USA).

\section{Migration assays}

Migration assays were performed in 24 Transwell plates across $5 \mu \mathrm{m}$ polycarbonate membranes (Costar, Corning Incorporated, NY, USA). DC ( $2 \times 10^{5}$ cells) were re suspended 
in DMEM containing $2 \%$ FCS and placed on the upper chamber. The lower chamber contained $600 \mu \mathrm{l}$ of DMEM $2 \%$ FCS supplemented with $20 \mathrm{ng} \cdot \mathrm{ml}^{-1} \mathrm{IL}^{-4}$ and $20 \mathrm{ng} \cdot \mathrm{ml}^{-1} \mathrm{GM}-$ $\mathrm{CSF}$; or $\mathrm{CM}$ in the presence or not of $\mathrm{Neo}$, which were equally supplemented with IL-4 and GM-CSF. After incubation for $4 \mathrm{~h}$ at $37^{\circ} \mathrm{C}$, cells in the lower chamber were recovered and counted with a FACS Calibur. Migration of monocytes was similar to DC except that it was performed for $2 \mathrm{~h}$ and each well contained $600 \mu \mathrm{l}$ of DMEM $2 \%$ FCS, CM in the presence or not of Neo and atropine.

\section{Western Blotting}

Trophoblast cells $\left(2 \times 10^{6}\right)$ were cultured for $24 \mathrm{~h}$ at $37^{\circ} \mathrm{C}$, washed with PBS supplemented with proteases inhibitors and pellets immediately frozen in dry ice. Samples were separated by $10 \%$ SDS-PAGE, transferred to polyvinylidene difluoride membranes (Sigma-Aldrich) and blotted with the indicated antibodies overnight at $4{ }^{\circ} \mathrm{C}$ and specific bands revealed with $\mathrm{ECL}$ (Amersham Biosciences) using mouse monoclonal IgG anti-ChAT (Chemicon International), goat polyclonal IgG anti-AChE (Santa Cruz Biotechnologies) and HRP-labeled secondary polyclonal antibodies (Sigma-Aldrich). The breast cancer cell line MCF-7 and DC were employed as positive controls for AChE and ChAT expression.

\section{Fluorescence microscopy}

Trophoblast cells $\left(5 \times 10^{4}\right)$ were grown over glass slides and cultured for $24 \mathrm{~h}$ at $37^{\circ} \mathrm{C}$. Cells were washed with PBS, fixed with methanol and permeabilized using PBS- $1 \%$ BSA-0.5\% saponin buffer during $15 \mathrm{~min}$. Slides were incubated overnight at $4^{\circ} \mathrm{C}$ with mouse IgG $\mathrm{mAb}$ anti-ChAT or goat polyclonal IgG anti-AChE, washed and incubated with FITC-conjugated secondary antibodies anti-mouse or anti-goat IgG for 2 h. DAPI staining (Cell Signaling, Danvers, MA, USA) was performed for $10 \mathrm{~min}$ in darkness and microphotographs acquired using a IX71® Olympus inverted fluorescence microscope (Olympus, Center Valley, PA, USA) and Micro-Manager Software. Negative control was performed in the absence of antiChAT or anti-AChE Ab.

This article is protected by copyright. All rights reserved. 


\section{Statistical analysis}

The significance of the results was analyzed by Student's $t$ test or Mann-Whitney test for nonparametric samples. When multiple comparisons were necessary, the Student-NewmanKeuls test was used after analysis of variance. Differences between groups were considered significant at $\mathrm{P}<0.05$ using the GraphPad Prism4 software (GraphPad, San Diego, CA, USA).

\section{Reagents and Antibodies}

Endotoxin-free reagents and plastic materials were used in all experiments. RPMI-1640 and PBS were purchased from HyClone Laboratories (Logan, UT, USA). DMEM was from Life Technologies, Argentina. Fetal calf serum (FCS) and penicillin/streptomycin were purchased from Invitrogen Life Technologies (Grand Island, NY, USA). 24-well flat bottom polystyrene plates, recombinant human interleukin-4 (IL-4), fluorescein isothiocyanate (FITC)- or phycoerythrin (PE)-conjugated anti- CD1a, CD14, CD83, CD86, HLA-DR, IL-10, TNF- $\alpha$ and control isotype-matched Abs were from BD Pharmingen (San Diego, CA, USA). Recombinant human granulocyte-macrophage colony-stimulating factor (GM-CSF), atropine and carbachol were from Sigma-Aldrich (St. Louis, MO, USA) and neostigmine from Phadapharma Laboratories (Buenos Aires, Argentina). Anti-ChAT antibody (MAB5350) was from Chemicon International (Ontario, Canada) and anti-AChE antibody (N-19) b (sc-6431) was from Santa Cruz Biotechnology (Heidelberg, Germany). Secondary polyclonal IgG labeled with HRP were from Sigma-Aldrich (St. Louis, MO, USA) and ECL detection kit from Amersham Biosciences (Wauwatosa, USA).

\section{Results}

\section{ACh produced by trophoblast cells induce the migration of maternal monocytes and dendritc cells}

Taking into account the relevance of DC and macrophages in the generation of the maternoplacental interface and that they are able to respond to ACh stimulation, we evaluated the ability of first trimester trophoblast cells conditioned media $(\mathrm{CM})$ to modulate maternal

This article is protected by copyright. All rights reserved. 
monocytes and DC migration and the effect of acetylcholine. For that purpose migration assays were performed using CD14+ cells or DC in the presence of CM from trophoblast cells cultured with or without neostigmine (Neo), an acetylcholinesterase inhibitor that increases endogenous ACh levels, or atropine, a competitive inhibitor of muscarinic ACh receptors. As shown in Figure $1 \mathrm{~A}, \mathrm{CM}$ of first trimester trophoblast cells induced a higher monocyte migration rate than DMEM medium alone. On the other hand, when trophoblast cells were grown in the presence of $20 \mu \mathrm{M}$ Neo there was an increased monocyte migration and the effect was blocked by atropine.

In migration assays with DC, we observed a marked increase of DC migration when they were exposed to trophoblast cell conditioned media (CM) compared with DMEM $2 \%$ FCS alone (Figure 1B). The treatment of trophoblast cells with Neo could not further increase DC migration compared with trophoblast cells alone, which produced enough chemokine levels for maximum migration capacity of DC. Atropine $(100 \mathrm{nM})$ had no effect on DC migration induced by trophoblast conditioned media obtained in the presence or absence of neostigmine (not shown).

\section{ACh modulates the cytokine production from monocyte after the interaction with trophoblast cells}

We next investigated if acetylcholine modify the activation profile of monocytes attracted towards trophoblast cells (Thaxton and Sharma 2010). Maternal monocytes were co-cultured with trophoblast cells in the absence or presence of $20 \mu \mathrm{M} \mathrm{Neo}$ and atropine and after $24 \mathrm{~h}$, IL-10 and TNF- $\alpha$ production were quantified by FACS. Figure 2 shows increased IL-10 production while decreased TNF- $\alpha$ in CD14+ cells after interaction with trophoblast cells and this effect was potentiated in the presence of Neo. The effect of Neo was prevented by atropine.

This article is protected by copyright. All rights reserved. 


\section{ACh condition DC profile during their interaction with trophoblast cells}

Since the physiological inflammatory response during the implantation shoud be shift toward a tolerogenic one, we investigated ACh ability of condition maternal DC to a tolerogenic profile. Then, maternal DC were co-cultured with trophoblast cells in the presence of Neo for $24 \mathrm{~h}$ and then cytokine release, activation and maturation markers were quantified. As shows Figure $3 \mathrm{~A}$ trophoblast-DC interaction increased the levels of IL-10 and MCP-1 production. In parallel, Neo increased the levels of IL-10 and MCP-1 through mAChR in these co-cultures but did not modulate IL- 6 or TNF-a production. In fact, the expression of HLA-DR, CD86 and CD83, markers of DC activation and maturation, showed no changes when DC were co-cultured with trophoblast cells in the presence or absence of Neo (Figure 3B), suggesting that DC in the presence of Neo might be in an immature state producing IL10.

\section{Trophoblast cells increase chemokine expression through ACh stimulation}

Taking into account that ACh produced by trophoblast cells increase the migration of monocytes and DC, we analyzed the expression of monocyte and DC chemoattractant proteins, MCP-1, MIP-1 $\alpha$ and RANTES and its modulation by acetylcholine. Trophoblast cells treated with $20 \mu \mathrm{M}$ neostigmine increased the expression of the three chemokines at the same extent than elicited by the muscarinic ACh receptor agonist carbachol (10 nM) and the effect was inhibited by the competitive inhibitor of muscarinic ACh receptors atropine (Figure 4A).

Finally, to confirm the enodogenous ACh production we explored ChAT and AChE expression in the Swan-71 cells by RT-PCR, Western Blot and immunofluorescence microscopy. As shown in Figures 4B, both enzymes are expressed in cytotrophoblast cells at mRNA and protein level and they were both localized in the cytoplasm as revealed by immunofluorescence. In addition, muscarinic acetylcholine receptor expression was assessed in Swan-71 cells. Figure $4 \mathrm{C}$ shows the expression of $M 1, M 2, M 3$ and M4 subtypes of mAChRs, with a predominant M4 subtype expression.

This article is protected by copyright. All rights reserved. 
The present results suggest that endogenous ACh prodution by trophoblast cells induce monocyte and DC migration increassing MCP-1, MIP-1 $\alpha$ and RANTES expression.

\section{Discussion}

Successful embryo implantation occurs followed by a local physiological and sterile inflammatory response, subsequently redirected towards a tolerogenic predominant profile. Consistently, a deregulated persistent inflammatory response during early placentation has been associated with pregnancy complications such as spontaneous recurrent abortion and preeclampsia (Girardi et al 2006; Kwak-Kim et al 2010; Redman and Sargent 2010; Dekel et al 2010). By means of co-cultures of a human first trimester trophoblast cell line with monocytes or DC from fertile women, here we present evidence to support that non neuronal ACh from trophoblast cells can modulate the migration and condition the activation of CD14+ cells and DC profile. These conclusions are based on two main observations. First, through endogenous ACh production, trophoblast cells modulate monocyte and DC migration and particularly in monocytes is prevented by atropine. Besides, human trophoblast cell line Swan-71 increased the expression of antigen presenting cell-attracting chemokines (MCP-1 and MIP-1 $\alpha$ ) and RANTES which can also interacts with CCR5 as MIP-1 $\alpha$. Second, the interaction of trophoblast cells with antigen presenting cells in vitro conditions their activation profile. DC displayed an increase in the synthesis of anti-inflammatory IL-10 and the chemokine MCP-1 by endogenous ACh with no changes in TNF- $\alpha$ and IL-6 in trophoblastdendritic cell co-cultures. In parallel, the contact with trophoblast cells and neostigmine, CD14+ cells modulate their marker profile to a predominant immunosuppressant phenotype, an effect that is prevented by atropine.

Antigen presenting cells secrete angiogenic factors that induce vascular growth in receptive deciduas and shape the cytokine profile at the materno-placental interface (Dominguez et al 2005; Dekel et al 2010). They have to migrate to the interface and, consistently, several factors synthesized by trophoblast cells were proposed to increase DC, monocytes and macrophages migration as well as their differentiation to an immunosuppressant

This article is protected by copyright. All rights reserved. 
predominant response, the immune profile characteristic of midgestation (Fest et al 2007; Huang et al 2008; Fraccaroli et al 2009a; Fraccaroli et al 2009b; Gomez-Lopez et al 2010; Salamone et al 2012; Grasso et al 2014). Interestingly, non neuronal ACh released by placental trophoblast cells varies with gestational age with a maximum at 20-22 weeks in humans and decreases thereafter (Sastry and Janson 1997; Tayebati et al 1997; Tayebati et al 1998; Bhuiyan et al 2006), coincident with the pattern of immunosuppressant predominant microenvironment at the maternal-placental interface (Mor and Cardenas 2010). Our results are in line with this observation showing that acetylcholine released by cytotrophoblast cells not only facilitates monocyte migration but it also modulates monocyte/macrophage functional phenotype to favor an immunosuppressant milieu essential for homeostasis maintenance. This promoting effect of non neuronal cholinergic system on cell migration has been previously shown in other cell types such as keratinocytes and granulocytes (Wessler and Kirkpatrick 2008). Our results indicate that the treatment of trophoblast cells with Neo could not further increase DC migration compared with trophoblast cells alone. Considering that chemokine expression levels did increase with neostigmine, this result strongly suggests that functional chemokine levels released by $\mathrm{Tb}$ cells were enough for maximum migration capacity of DC.

Here we have identified monocyte and DC attracting chemokines MCP-1, MIP-1a and RANTES as key molecules which synthesis and release by trophoblast cells was synergized by non neuronal acetylcholine. MCP-1 is a well known chemoattractant of monocytes and macrophages often released with pro-inflammatory cytokines that activate macrophages in an inflammatory activation profile (Mosser and Edwards 2008; Biswas et al 2012; Sica and Mantovani 2012). Since an enhanced pro-inflammatory reaction would be deleterious for placentation and adequate fetal growth, it is conceivable that trophoblast endogenous acetylcholine had a dual role by inducing MCP-1 release to attract monocytes and dendritic cells, and in parallel it would favor immunosuppressant cytokine production and phenotype expression on attracted cells, as derived from our present results.

This article is protected by copyright. All rights reserved. 
The modulatory effect of acetylcholine on dendritic cell functional profile through muscarinic ACh receptors has been documented and it appears strongly dependent on their maturation status (Liu T et al 2010; Salamone et al 2011). In fact, cholinergic stimuli added to mature DC prevented HLA-DR expression and TNF-a production (Salamone et al 2011). This observation supports the ability of trophoblast cells to condition or 'educate' DC to express a tolerogenic profile that contributes to immune homeostasis maintenance at the maternal-fetal compartment (Salamone et al 2012). Our present results confirm the trophoblast-DC interaction as a permanent regulatory source for immunosuppression and provide new evidence on how endogenous acetylcholine modulates this interaction.

In line with a boosting effect of endogenous acetylcholine in the normal human maternalplacental interaction, microarray studies of term placenta from women treated with choline showed a decrease in the placental and circulating levels of the antiangiogenic factor fmslike tyrosine kinase-1 (sFLT1), proposed as a preeclampsia risk biomarker (Jiang et al 2013). The effect was confirmed in a human trophoblast cell line and was associated with an enhanced acetylcholine signaling. On the other hand, an early observation made in pregnancies complicated by preeclampsia indicated a very low synthesis of ACh in trophoblast cells undergoing advanced cell degeneration (Satyanarayana 1986).

Based on the potential homeostatic role of non-neuronal cholinergic system in human placenta and immune cells, as well as the diverse circuits involving antigen presenting cells in normal and pathologic pregnancies, our present results support a novel role of endogenous acetylcholine synthesized by trophoblast cells to modulate antigen presenting cell migration favoring an immunosuppressant profile.

\section{Author's Contributions}

DP, EG and GC performed all the experiments on trophoblast cells and co-cultures, obtained and characterized blood monocytes, carried out RT-PCR, Western blotting, immunocytochemistry assay and migration of antigen presenting cells; SG and GS differentiated and characterized DC from human blood samples, performed FACS analysis

This article is protected by copyright. All rights reserved. 
and ELISA; WS obtained blood samples and assessed clinical data; CPL, RR and GS designed the whole study, discussed the results and prepared the manuscript.

\section{Declaration of interest, Funding and Acknowledgements}

The authors declare that they have no conflict of interest. This work was funded by the National Agency of Sciences and Technology ANPCyT (PICT 2011-0144; PICT 2013-1632) and University of Buenos Aires (UBACyT 20020090200034 to RR and UBACyT 2014-2017 to $\mathrm{CPL})$.

\section{References}

Abrahams VM, Kim YM, Straszewski SL, et al (2004) Macrophages and apoptotic cell clearance during pregnancy. Am J Reprod Immunol 51:275-82. doi: 10.1111/j.16000897.2004.00156.x

Aluvihare VR, Kallikourdis M, Betz AG (2005) Tolerance, suppression and the fetal allograft. J Mol Med (Berl) 83:88-96. doi: 10.1007/s00109-004-0608-2

Aplin JD, Straszewski-Chavez SL, Kalionis B, et al (2006) Trophoblast differentiation: progenitor cells, fusion and migration -- a workshop report. Placenta 27 Suppl A:S1413. doi: 10.1016/j.placenta.2006.01.011

Bhuiyan MB, Murad F, Fant ME (2006) The placental cholinergic system: localization to the cytotrophoblast and modulation of nitric oxide. Cell Commun Signal 4:4. doi: 10.1186/1478-811X-4-4

Biswas S, Chittezhath M, Shalova I, Lim J (2012) Macrophage polarization and plasticity in health and disease. Immunol Res 53:11-24.

Blois SM, Ilarregui JM, Tometten M, et al (2007) A pivotal role for galectin-1 in fetomaternal tolerance. Nat Med 13:1450-7. doi: 10.1038/nm1680

Borovikova L V, Ivanova S, Zhang M, et al (2000) Vagus nerve stimulation attenuates the systemic inflammatory response to endotoxin. Nature 405:458-62. doi: $10.1038 / 35013070$

Dekel N, Gnainsky Y, Granot I, Mor G (2010) Inflammation and implantation. Am J Reprod Immunol 63:17-21. doi: 10.1111/j.1600-0897.2009.00792.x

Dominguez F, Ya M, Leo D De (2005) Embryonic implantation and leukocyte transendothelial migration : different processes with similar players? FASEB J Fed Am Soc Exp Biol 19:1056-60. doi: 10.1096/fj.05-3781hyp

This article is protected by copyright. All rights reserved. 
Fest S, Aldo PB, Abrahams VM, et al (2007) Trophoblast-macrophage interactions: a regulatory network for the protection of pregnancy. Am J Reprod Immunol 57:55-66. doi: 10.1111/j.1600-0897.2006.00446.x

Fraccaroli L, Alfier i J, Leiros C, Ramhorst R (2009a) Immunomodulatory effects of chemokines during the early implantation window. Front Biosci 1:288-98.

Fraccaroli L, Alfieri J, Larocca L, et al (2009b) A potential tolerogenic immune mechanism in a trophoblast cell line through the activation of chemokine-induced T cell death and regulatory T cell modulation. Hum Reprod 24:166-75. doi: 10.1093/humrep/den344

Girardi G, Yarilin D, Thurman JM, et al (2006) Complement activation induces dysregulation of angiogenic factors and causes fetal rejection and growth restriction. J Exp Med 203:2165-75. doi: 10.1084/jem.20061022

Gomez-Lopez N, Guilbert L, Olson DM (2010) Invasion of the leukocytes into the fetalmaternal interface during pregnancy. J Leukoc Biol 88:625-33. doi: 10.1189/jlb.1209796

Gordon S, Taylor P Monocyte and macrophage heterogeneity. 2005 5:953-64.

Grando SA, Kawashima K, Kirkpatrick CJ, et al (2012) The non-neuronal cholinergic system: basic science, therapeutic implications and new perspectives. Life Sci 91:969-72. doi: 10.1016/j.Ifs.2012.10.004

Grasso E, Paparini D, Hauk V, et al (2014) Differential Migration and Activation Profile of Monocytes after Trophoblast Interaction. PLoS One 9:1-10. doi: 10.1371/journal.pone.0097147

Harris LK. (2011) IFPA Gabor Than Award lecture: Transformation of the spiral arteries in human pregnancy: key events in the remodelling timeline. Placenta 32:154-8.

Huang Y, Zhu X, Du M, Li D (2008) Human trophoblasts recruited T lymphocytes and monocytes into decidua by secretion of chemokine CXCL16 and interaction with CXCR6 in the first-trimester pregnancy. J Immunol 180:2367-75.

Jiang X, Bar HY, Yan J, et al (2013) A higher maternal choline intake among third-trimester pregnant women lowers placental and circulating concentrations of the antiangiogenic factor fms-like tyrosine kinase-1 ( sFLT1 ). FASEB J Fed Am Soc Exp Biol 27:12451253. doi: 10.1096/fj.12-221648

Kwak-Kim J, Park J, Ahn H, et al (2010) Immunological modes of pregnancy loss. Am J Reprod Immunol 63:611-23.

Laskarin G, Kämmerer U, Rukavina D, et al (2007) Antigen-presenting cells and maternofetal tolerance: an emerging role for dendritic cells. Am J Reprod Immunol 58:255-67. doi: 10.1111/j.1600-0897.2007.00511.x

Leber A, Teles A, Zenclussen AC (2010) Regulatory T cells and their role in pregnancy. Am J Reprod Immunol 63:445-59. doi: 10.1111/j.1600-0897.2010.00821.x

This article is protected by copyright. All rights reserved. 
Liu T, Xie C, Chen X, Zhao F, Liu AM, Cho DB, Chong J YP (2010) Role of muscarinic receptor activation in regulating immune cell activity in nasal mucosa. Allergy 65:96977.

Mor G (2008) Inflammation and pregnancy: the role of toll-like receptors in trophoblastimmune interaction. Ann N Y Acad Sci 1127:121-8. doi: 10.1196/annals.1434.006

Mor G, Cardenas I (2010) The immune system in pregnancy: a unique complexity. Am J Reprod Immunol 63:425-433. doi: 10.1111/j.1600-0897.2010.00836.x.The

Mor G, Straszewski-Chavez, SL. Abrahams V (2006) Macrophage-trophoblast interactions. Methods Mol Med 122:149-163.

Mosser DM, Edwards JP (2008) Exploring the full spectrum of macrophage activation. Nat Rev Immunol 8:958-969. doi: 10.1038/nri2448.Exploring

Nagamatsu T, Schust D (2010) The contribution of macrophages to normal and pathological pregnancies. Am J Reprod Immunol 63:460-71.

Olubadewo JO, Rama Sastry B V (1978) Human placental cholinergic system: stimulationsecretion coupling for release of acetylcholine from isolated placental villus. $J$ Pharmacol Exp Ther 204:433-45.

Pérez Leirós C, Ramhorst R (2013) Tolerance induction at the early maternal-placental interface through selective cell recruitment and targeting by immune polypeptides. Am $\mathrm{J}$ Reprod Immunol 69:359-68.

Plaks V, Birnberg T, Berkutzki T, et al (2008) Uterine DCs are crucial for decidua formation during embryo implantation in mice. Analysis. doi: 10.1172/JCI36682DS1

Redman C, Sargent I (2010) Immunology of pre-eclampsia. Am J Reprod Immunol 63:53443.

Renaud S, Graham C (2008) The role of macrophages in utero-placental interactions during normal and pathological pregnancy. Immunol Invest 37:535-64.

Salamone G, Fraccaroli L, Gori S, et al (2012) Trophoblast cells induce a tolerogenic profile in dendritic cells. Hum Reprod 27:2598-606. doi: 10.1093/humrep/des208

Salamone G, Lombardi G, Gori S, et al (2011) Cholinergic modulation of dendritic cell function. J Neuroimmunol 236:47-56. doi: 10.1016/j.jneuroim.2011.05.007

Sastry B, Janson V (1997) Cholinergic markers in transformed trophoblast cells: BeWo and JAr cells. Cell Mol Biol 43:559-65.

Satyanarayana M (1986) A correlative review of acetylcholine synthesis in relation to histopathology of the human syncytiotrophoblast. Acta Obstet Ginecol Scand 65:56772.

Sica A, Mantovani A (2012) Science in medicine Macrophage plasticity and polarization : in vivo veritas. J Clin Invest 122:787-795. doi: 10.1172/JCI59643DS1

This article is protected by copyright. All rights reserved. 
Straszewski-Chavez SL, Abrahams VM, Alvero AB, et al (2009) The isolation and characterization of a novel telomerase immortalized first trimester trophoblast cell line, Swan 71. Placenta 30:939-48. doi: 10.1016/j.placenta.2009.08.007

Tayebati S, Sabbatini M, Zaccheo D, Amenta F (1997) Muscarinic cholinergic receptor subtypes expression by human placenta. Neurosci Lett 221:208-12.

Tayebati S, Vitaiol i L, Zaccheo D, Amenta F (1998) Autoradiographic localisation of muscarinic cholinergic receptor subtypes in human placenta. Neurosci Lett 247:167-70.

Terness P, Kallikourdis M, Betz AG, et al (2007) Tolerance signaling molecules and pregnancy: IDO, galectins, and the renaissance of regulatory T cells. Am J Reprod Immunol 58:238-54. doi: 10.1111/j.1600-0897.2007.00510.x

Thaxton J, Sharma S (2010) Interleukin-10: a multi-faceted agent of pregnancy. Am J Reprod Immunol 63:482-91.

Wessler I, Kirkpatrick CJ (2008) Acetylcholine beyond neurons: the non-neuronal cholinergic system in humans. Br J Pharmacol 154:1558-71. doi: 10.1038/bjp.2008.185

Wessler I, Michel-Schmidt R, Brochhausen C, Kirkpatrick CJ (2012) Subcellular distribution of choline acetyltransferase by immunogold electron microscopy in non-neuronal cells: placenta, airways and murine embryonic stem cells. Life Sci 91:977-80. doi: 10.1016/j.Ifs.2012.05.012

Abrahams VM, Kim YM, Straszewski SL, Romero R, Mor G. Macrophages and apoptotic cell clearance during pregnancy. Am J Reprod Immunol. 2004; 51:275-82.

Aluvihare VR, Kallikourdis M, Betz AG. Tolerance, suppression and the fetal allograft. J Mol Med (Berl). 2005; 83:88-96.

Aplin JD, Straszewski-Chavez SL, Kalionis B, Dunk C, Morrish D, Forbes K, Baczyk D, Rote $\mathrm{N}$, Malassine A, Knöfler M. Trophoblast differentiation: progenitor cells, fusion and migration -- a workshop report. Placenta. 2006; 27 Suppl A:S141-3.

Bhuiyan MB, Murad F, Fant ME. The placental cholinergic system: localization to the cytotrophoblast and modulation of nitric oxide. Cell Commun Signal. 2006; 4:4.

Biswas S, Chittezhath M, Shalova I, Lim J-Y. Macrophage polarization and plasticity in health and disease. Immunol Res. 2012; 53:11-24.

Blois SM, Ilarregui JM, Tometten M, Garcia M, Orsal AS, Cordo-Russo R, Toscano MA, Bianco GA, Kobelt P, Handjiski B, Tirado I, Markert UR, Klapp BF, Poirier F, SzekeresBartho J, Rabinovich GA, Arck PC. A pivotal role for galectin-1 in fetomaternal tolerance. Nat Med. 2007; 13:1450-7.

Borovikova LV, Ivanova S, Zhang M, Yang H, Botchkina GI, Watkins LR, Wang H, Abumrad $\mathrm{N}$, Eaton JW, Tracey KJ. Vagus nerve stimulation attenuates the systemic inflammatory response to endotoxin. Nature. 2000; 405:458-62.

Dekel N, Gnainsky Y, Granot I, Mor G. Inflammation and implantation. Am J Reprod Immunol. 2010; 63:17-21.

This article is protected by copyright. All rights reserved. 
Dominguez F, Yáñez-Mó M, Sanchez-Madrid F, Simon C. Embryonic implantation and leukocyte transendothelial migration: different processes with similar players ? FASEB J Fed Am Soc Exp Biol. 2005; 19:1056-60.

Fest S, Aldo PB, Abrahams VM, Visintin I, Alvero A, Chen R, Chavez SL, Romero R, Mor G. Trophoblast-macrophage interactions: a regulatory network for the protection of pregnancy. Am J Reprod Immunol. 2007; 57:55-66.

Fraccaroli L, Alfier i J, Leiros C, Ramhorst R. Immunomodulatory effects of chemokines during the early implantation window. Front Biosci. 2009a; 1:288-98.

Fraccaroli L, Alfieri J, Larocca L, Calafat M, Mor G, Perez Leirós C, Ramhorst R. A potential tolerogenic immune mechanism in a trophoblast cell line through the activation of chemokine-induced T cell death and regulatory T cell modulation. Hum Reprod. 2009b; 24:166-75.

Girardi G, Yarilin D, Thurman JM, Holers VM \& Salmon JE. Complement activation induces dysregulation of angiogenic factors and causes fetal rejection and growth restriction. $J$ Exp Med. 2006; 203:2165-75.

Gomez-Lopez N, Guilbert L, Olson DM. Invasion of the leukocytes into the fetal-maternal interface during pregnancy. J Leukoc Biol. 2010; 88:625-33.

Gordon S, Taylor P Monocyte and macrophage heterogeneity. Nat Rev Immunol. 2005; 5:953-64.

Grando SA, Kawashima K, Kirkpatrick CJ, Meurs H \& Wessler I. The non-neuronal cholinergic system: basic science, therapeutic implications and new perspectives. Life Sci. 2012; 91:969-72.

Grasso E, Paparini D, Hauk V, Salamone G, Leiros CP, Ramhorst R. Differential Migration and Activation Profile of Monocytes after Trophoblast Interaction. PLoS One. 2014; 9:1-10.

Harris LK. IFPA Gabor Than Award lecture: Transformation of the spiral arteries in human pregnancy: key events in the remodelling timeline. Placenta. 2011; 32:154-8.

Huang Y, Zhu X, Du M, Li D-J. Human trophoblasts recruited T lymphocytes and monocytes into decidua by secretion of chemokine CXCL16 and interaction with CXCR6 in the first-trimester pregnancy. J Immunol. 2008; 180:2367-75.

Jiang X, Bar HY, Yan J, Jones S, Brannon PM, West AA, Perry CA, Ganti A, Pressman E, Devapatla S, Vermeylen F, Wells MT, Caudill MA. A higher maternal choline intake among third-trimester pregnant women lowers placental and circulating concentrations of the antiangiogenic factor fms-like tyrosine kinase-1 ( sFLT1). FASEB J Fed Am Soc Exp Biol. 2013; 27:1245-1253.

Kwak-Kim J, Park J, Ahn H, Kim J, Gilman-Sachs A. Immunological modes of pregnancy loss. Am J Reprod Immunol. 2010; 63:611-23.

Laskarin G, Kämmerer U, Rukavina D, Thomson AW, Fernandez N, Blois SM. Antigenpresenting cells and materno-fetal tolerance: an emerging role for dendritic cells. Am J Reprod Immunol. 2007; 58:255-67.

This article is protected by copyright. All rights reserved. 
Leber A, Teles A, Zenclussen AC. Regulatory $T$ cells and their role in pregnancy. Am J Reprod Immunol. 2010; 63:445-59.

Liu T, Xie C, Chen X, Zhao F, Liu AM, Cho DB, Chong J YP. Role of muscarinic receptor activation in regulating immune cell activity in nasal mucosa. Allergy. 2010; 65:969-77.

Mor G. Inflammation and pregnancy: the role of toll-like receptors in trophoblast-immune interaction. Ann N Y Acad Sci. 2008; 1127:121-8.

Mor G, Cardenas I. The immune system in pregnancy: a unique complexity. Am J Reprod Immunol. 2010; 63:425-433.

Mor G, Straszewski-Chavez, SL. Abrahams V. Macrophage-trophoblast interactions. Methods Mol Med. 2006; 122:149-163.

Mosser DM, Edwards JP. Exploring the full spectrum of macrophage activation. Nat Rev Immunol. 2008; 8:958-969.

Nagamatsu T, Schust D. The contribution of macrophages to normal and pathological pregnancies. Am J Reprod Immunol. 2010; 63:460-71.

Olubadewo JO, Rama Sastry B V. Human placental cholinergic system: stimulationsecretion coupling for release of acetylcholine from isolated placental villus. J Pharmacol Exp Ther. 1978; 204:433-45.

Pérez Leirós C, Ramhorst R. Tolerance induction at the early maternal-placental interface through selective cell recruitment and targeting by immune polypeptides. Am J Reprod Immunol. 2013; 69:359-68.

Plaks V, Birnberg T, Berkutzki T, Sela S, Benyashar A, Kalchenko V, Mor G, Keshet E, Dekel N, Neeman M, Jung S. Uterine DCs are crucial for decidua formation during embryo implantation in mice. J Clin Invest. 2008; 118 3954-3965

Redman C, Sargent I. Immunology of pre-eclampsia. Am J Reprod Immunol. 2010; 63:53443.

Renaud S, Graham C. The role of macrophages in utero-placental interactions during normal and pathological pregnancy. Immunol Invest. 2008; 37:535-64.

Salamone G, Fraccaroli L, Gori S, Grasso E, Paparini D, Geffner J, Leirós CP, Ramhorst R. Trophoblast cells induce a tolerogenic profile in dendritic cells. Hum Reprod. 2012; 27:2598-606.

Salamone G, Lombardi G, Gori S, Nahmod K, Jancic C, Amaral MM, Vermeulen M, Español A, Sales ME, Geffner J. Cholinergic modulation of dendritic cell function. J Neuroimmunol. 2011; 236:47-56.

Sastry B, Janson V. Cholinergic markers in transformed trophoblast cells: BeWo and JAr cells. Cell Mol Biol. 1997; 43:559-65.

Satyanarayana M. A correlative review of acetylcholine synthesis in relation to histopathology of the human syncytiotrophoblast. Acta Obstet Ginecol Scand. 1986; 65:567-72.

This article is protected by copyright. All rights reserved. 
Sica A, Mantovani A. Macrophage plasticity and polarization: in vivo veritas. J Clin Invest. 2012; 122:787-795.

Straszewski-Chavez SL, Abrahams VM, Alvero AB, Aldo PB, Ma Y, Guller S, Romero R \& Mor $\mathrm{G}$. The isolation and characterization of a novel telomerase immortalized first trimester trophoblast cell line, Swan 71. Placenta. 2009; 30:939-48.

Tayebati S, Sabbatini M, Zaccheo D, Amenta F. Muscarinic cholinergic receptor subtypes expression by human placenta. Neurosci Lett. 1997; 221:208-12.

Tayebati S, Vitaiol i L, Zaccheo D, Amenta F. Autoradiographic localisation of muscarinic cholinergic receptor subtypes in human placenta. Neurosci Lett. 1998; 247:167-70.

Terness $P$, Kallikourdis $M$, Betz AG. Tolerance signaling molecules and pregnancy: IDO, galectins, and the renaissance of regulatory T cells. Am J Reprod Immunol. 2007; 58:238-54.

Thaxton J, Sharma S. Interleukin-10: a multi-faceted agent of pregnancy. Am J Reprod Immunol. 2010; 63:482-91.

Wessler I, Kirkpatrick CJ. Acetylcholine beyond neurons: the non-neuronal cholinergic system in humans. Br J Pharmacol. 2008; 154:1558-71.

Wessler I, Michel-Schmidt R, Brochhausen C \& Kirkpatrick CJ. Subcellular distribution of choline acetyltransferase by immunogold electron microscopy in non-neuronal cells: placenta, airways and murine embryonic stem cells. Life Sci. 2012; 91:977-80.

\section{Figure Legends}

Figure 1: ACh produced by trophoblast cells induce the migration of maternal monocytes and dendritc cells. A) Mo $\left(2 \times 10^{5}\right.$ cells $)$ were placed on the upper $5 \mu \mathrm{m}$ transwell chamber and the lower chamber contained conditioned media from trophoblast cells $(\mathrm{Tb})$ in the presence or absence of $20 \mu \mathrm{M}$ Neo and $100 \mathrm{nM}$ atropine. Migration was allowed for $2 \mathrm{~h}$ at $37^{\circ} \mathrm{C}$ and basal migration was assessed with DMEM 2\% FCS (Media). Cells recovered from the lower chamber were counted with a FACS Calibur. Values shown are $\mathrm{X} \pm$ S.E.M of different monocyte samples. ${ }^{*} \mathrm{P}<0.05 ;{ }^{* *} \mathrm{P}<0.01$ Mann-Whitney. B) Migration of $\mathrm{DC}\left(2 \times 10^{5}\right.$ cells $)$ was performed for $4 \mathrm{~h}$ at $37^{\circ} \mathrm{C}$ in $5 \mu \mathrm{m}$ transwell chambers with trophoblast cell conditioned media (Tb) obtained in the presence or absence of $20 \mu \mathrm{M}$ Neo

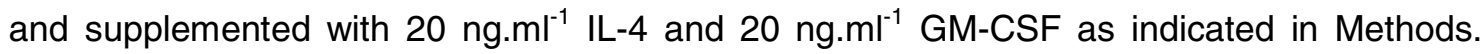
Cells recovered from the lower chamber were counted with a FACS Calibur. Basal migration

This article is protected by copyright. All rights reserved. 
values were obtained with DMEM 2\% FCS (Media). Results shown are $\mathrm{X} \pm$ S.E.M of 3 independent experiments with different DC samples. ${ }^{* *} \mathrm{P}<0.01$ Mann-Whitney.

Figure 2: ACh modulates the cytokine production from monocyte after the interaction with trophoblast cells. Monocytes were co-cultured with trophoblast cells $(\mathrm{Mo}+\mathrm{Tb})$ or not (Mo) in the presence or absence of $20 \mu \mathrm{M} \mathrm{Neo}$ and $100 \mathrm{nM}$ AT for $24 \mathrm{~h}$ at $37^{\circ} \mathrm{C}$. Cells were analyzed for TNF- $\alpha$ and IL-10 synthesis by FACS. Results are expressed as the percentage of CD14+TNF- $\alpha+$ and CD14+IL-10+ cells and are representative of at least 4 different monocyte samples run in duplicates. ${ }^{*} \mathrm{P}<0.05 ;{ }^{* *} \mathrm{P}<0.01$ Mann-Whitney. Dot plots representative of 4 experiments with different monocyte samples are also shown.

Figure 3: ACh condition DC profile during their interaction with trophoblast cells.

DC cultures or DC-Tb co-cultures were carried out alone or in the presence of $20 \mu \mathrm{M}$ Neostigmine (Neo) or with $20 \mu \mathrm{M}$ Neo and $100 \mathrm{nM}$ AT (Neo+AT) as described in Methods and supernatants collected for (A) IL-10, TNF- $\alpha$ MCP-1 or and IL- 6 determination by ELISA. Values represent $X \pm S$.E.M of at least 3 experiments. ${ }^{*} P<0.05 ;{ }^{\star} P<0.01$ Mann-Whitney.

B) DC cultured with $20 \mu \mathrm{M} \mathrm{Neo}(\mathrm{DC}+\mathrm{Neo})$ or co-cultured with trophoblast cells in the presence or not of $\mathrm{Neo}(\mathrm{DC}+\mathrm{Tb})$ and $(\mathrm{DC}+\mathrm{Tb}+\mathrm{Neo})$ were analyzed by FACS for the expression of HLA-DR, CD86 and CD83. The values represent the MFI and are expressed as $\mathrm{X} \pm \mathrm{S}$.E.M. One representative of 3 others run similarly.

Figure 4: Acetylcholine mediates MCP-1, MIP-1a and RANTES expression in trophoblast cells. A) Swan-71 cells were cultured in the presence of $20 \mu \mathrm{M}$ Neostigmine (Neo), $20 \mu \mathrm{M}$ Neo and $100 \mathrm{nM}$ AT (Neo-AT) or with 10 nM Carbachol (Carb), and MCP-1, MIP-1a and RANTES mRNA expression levels were determined. Band density was quantified with ImageJ, normalized to GAPDH expression and expressed as arbitrary units. Values represent $X \pm$ S.E.M of at least 3 independent experiments. ${ }^{*} P<0.05 ;{ }^{* *} P<0.01$

This article is protected by copyright. All rights reserved. 
Student-t test. Results shown are $\mathrm{X} \pm$ S.E.M of 3 independent experiments with different $\mathrm{DC}$ samples. ${ }^{* \star} \mathrm{P}<0.01$ Mann-Whitney.

B) Swan-71 cells were cultured and processed for ChAT and AChE expression as indicated in Methods. The mRNA expression of ChAT and AChE was normalized to GAPDH and visualized by transilumination. Results are representative of 3 similar experiments. Trophoblast cell extracts were separated on 10\% SDS-PAGE, blotted with anti-ChAT or antiAChE antibodies and bands normalized to $\beta$-actin were detected by ECL. Gels are representative of 3 others run similarly. The breast cancer cell line MCF-7 and DC are shown as positive controls (+) for AChE and ChAT expression respectively. Finally, Trophoblast cells $\left(5 \times 10^{4}\right)$ were grown over glass slides for immunofluorescence studies and immunostained with anti-ChAT or AChE and FITC-conjugated secondary antibodies (green fluorescence) or DAPI (blue). Microphotographs were acquired using a IX71® Olympus inverted fluorescence microscope and are representative of 3 similar experiments. Negative control (Negative) was performed with an irrelevant primary antibody. C) M1-M4 muscarinic AChR expression was determined by RT-PCR in trophoblast cells and band density was quantified with ImageJ, normalized to GAPDH expression and expressed as arbitrary units. Results are $\mathrm{X} \pm$ S.E.M of at least 3 determinations. ${ }^{*} \mathrm{P}<0.05$ ANOVA-Newman-Keuls.

This article is protected by copyright. All rights reserved. 
A
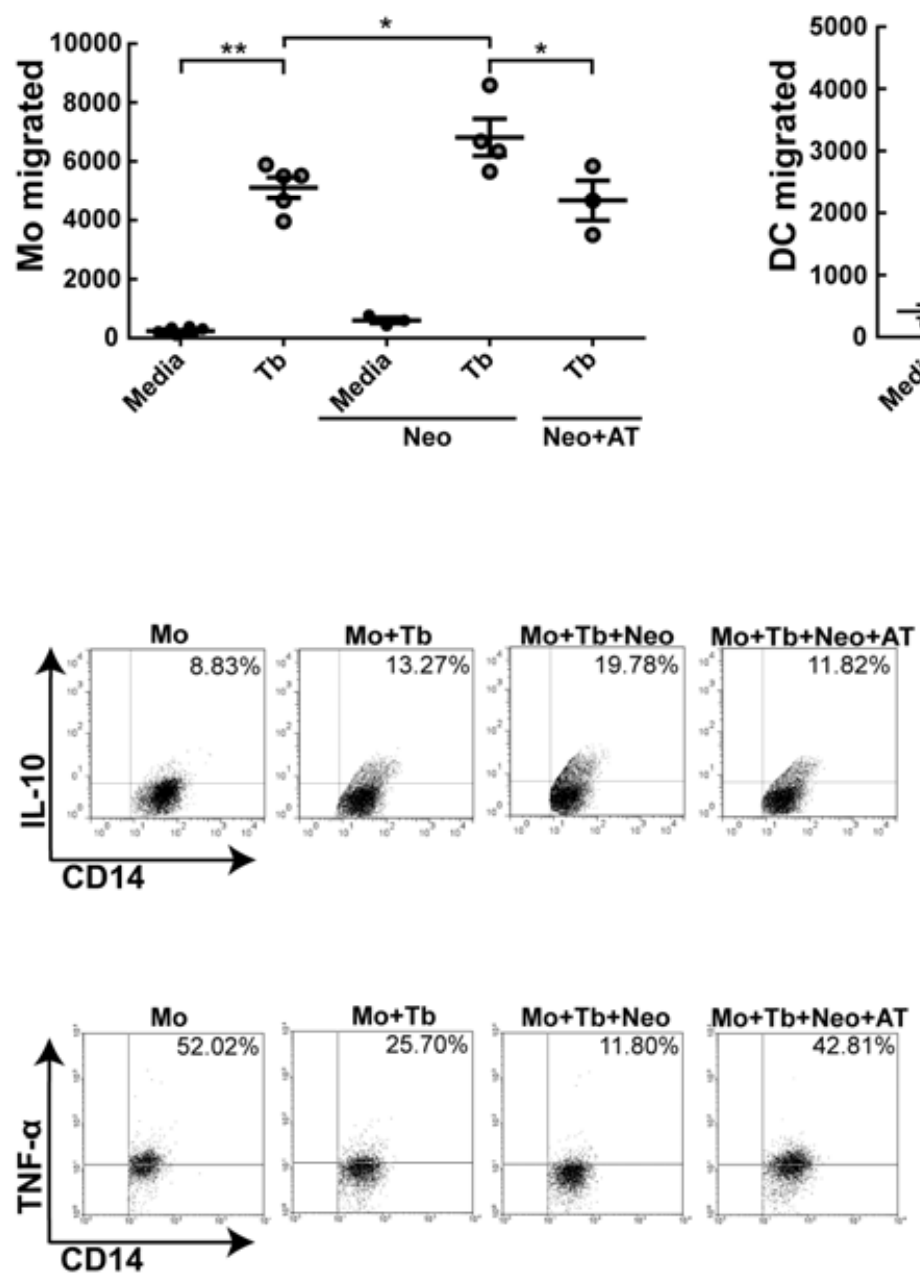

B

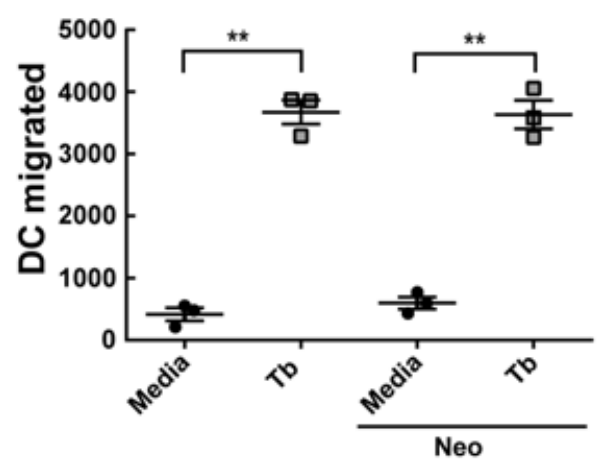

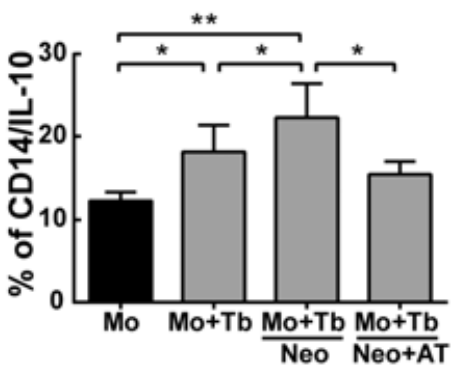

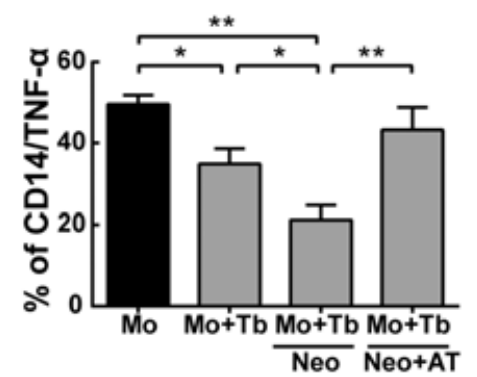

This article is protected by copyright. All rights reserved. 
A
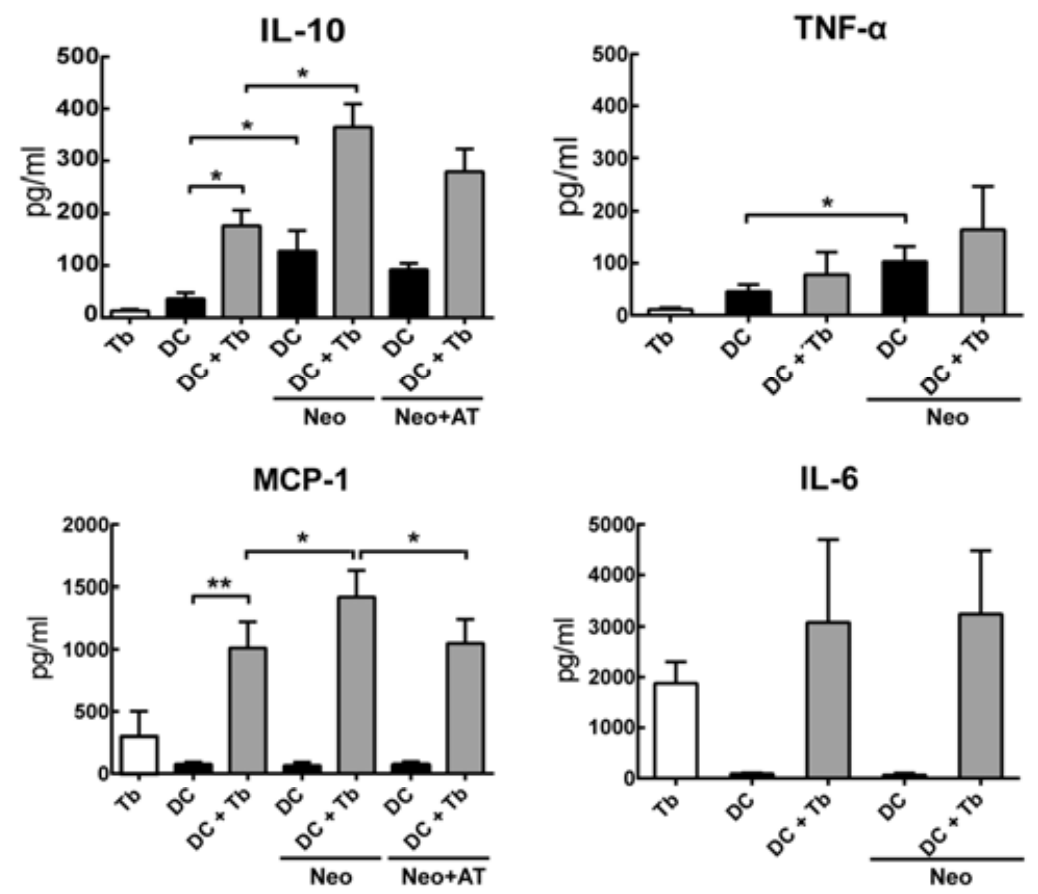

B
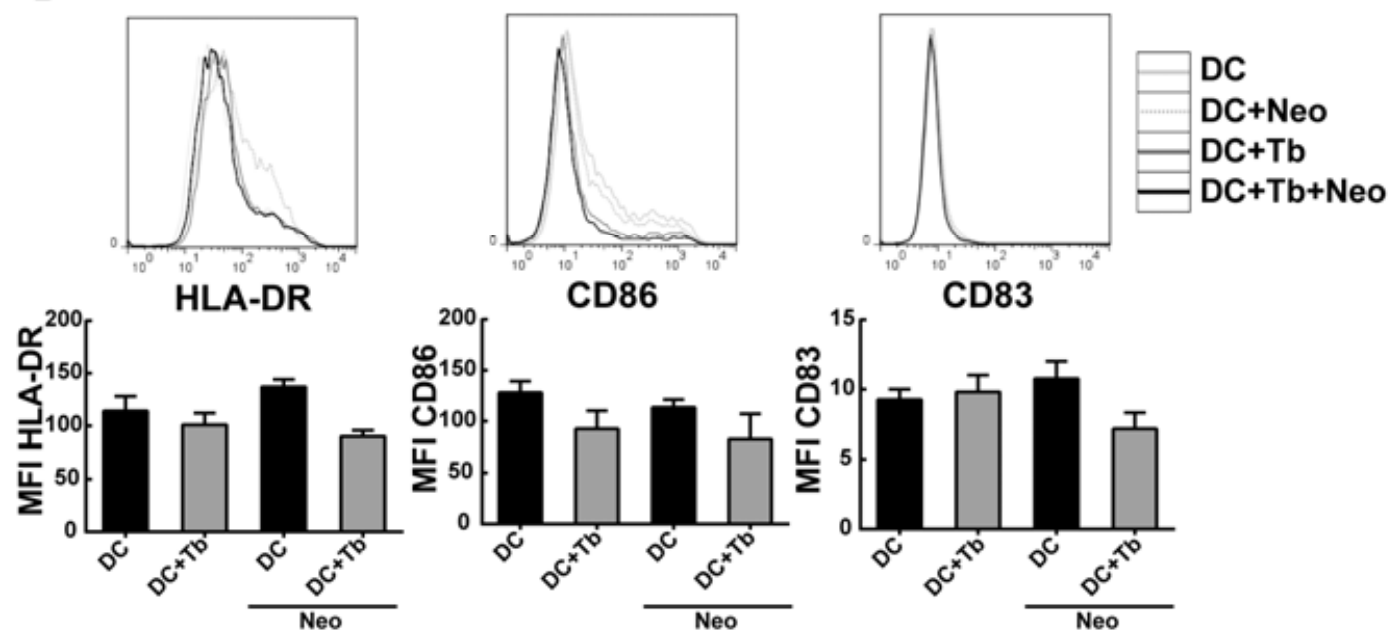

This article is protected by copyright. All rights reserved. 
A
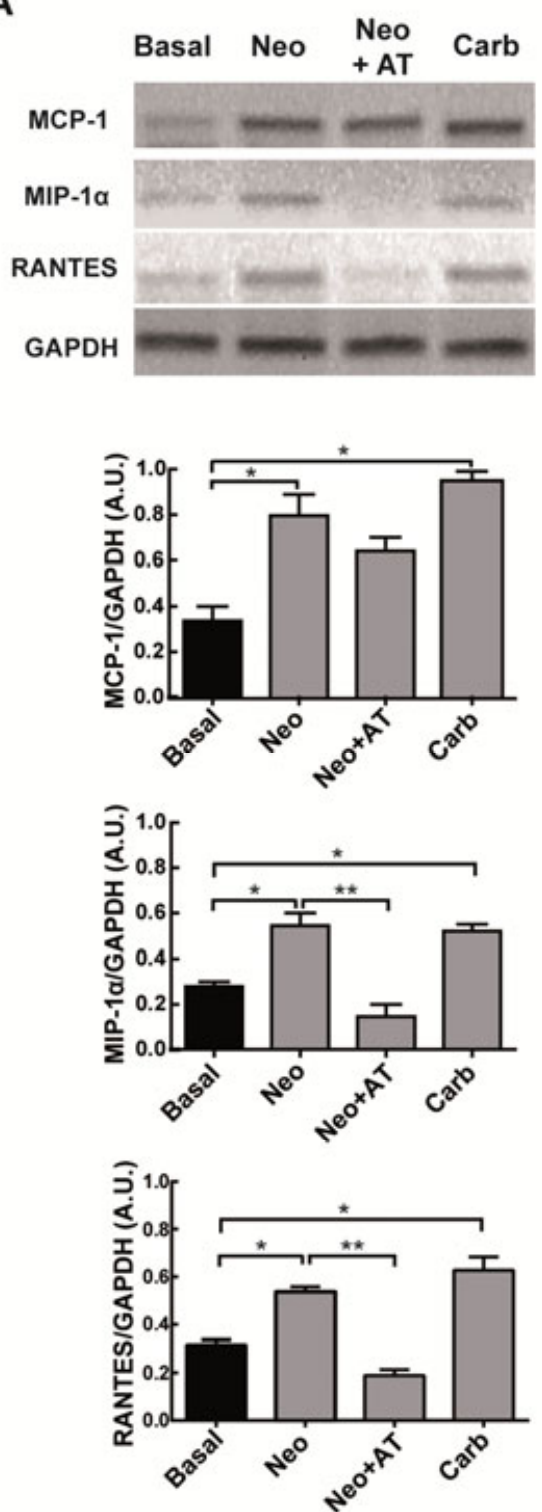

B

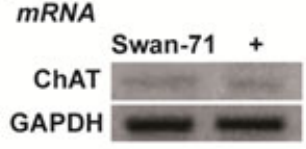

${ }^{\text {Protein }}$ Swan-71 +

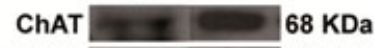

$\beta$-Actin $242 \mathrm{KDa}$

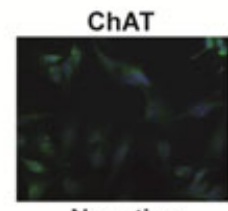

Negative

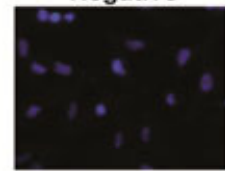

mRNA

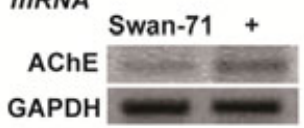

GAPDH $=0$

Protein
Swan-71 +

AChE $70 \mathrm{KDa}$

$\beta$-Actin $42 \mathrm{KDa}$

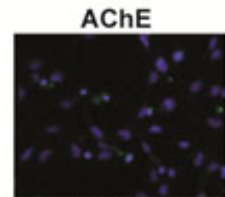

Negative

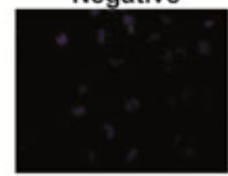

C

mRNA

(M1-M4mAChR)

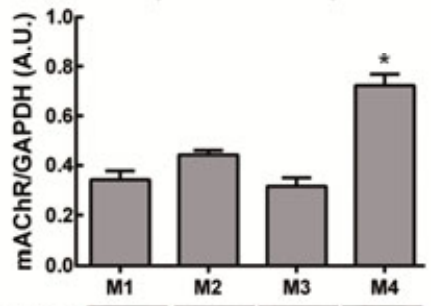

MAChR

GAPDH

This article is protected by copyright. All rights reserved. 


\section{Primer sequences}

AChE

\begin{tabular}{|c|c|c|}
\hline Sense & 5-AACTTTGCCCGCACAGGGGA-3` & \multirow{2}{*}{$\begin{array}{l}\text { Annealing } \mathrm{T}\left({ }^{\circ} \mathrm{C}\right) \\
55\end{array}$} \\
\hline Antisense & 5-GCCTCGTCGAGCGTGTCGGT-3 & \\
\hline \multicolumn{3}{|l|}{ ChAT } \\
\hline Sense & 5`GGAGATGTTCTGCTGCTATG-3` & \multirow{2}{*}{$\begin{array}{c}\text { Annealing } \mathrm{T}\left({ }^{\circ} \mathrm{C}\right) \\
57\end{array}$} \\
\hline Antisense & 5-GGAGGTGAAACCTAGTGGCA-3` & \\
\hline \multicolumn{3}{|c|}{ 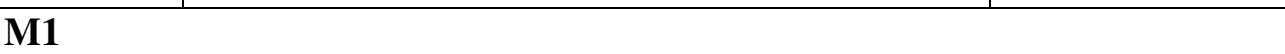 } \\
\hline Sense & 5'-GCTCCCCAAATACAGTCAAGAG-3' & \multirow{2}{*}{$\begin{array}{c}\text { Annealing } \mathrm{T}\left({ }^{\circ} \mathrm{C}\right) \\
56\end{array}$} \\
\hline Antisense & 5'-CAGCAGCAGGCGAAAGGTGT-3' & \\
\hline \multicolumn{3}{|c|}{ 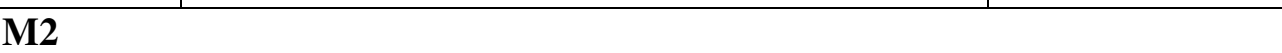 } \\
\hline Sense & 5'-GATGGCCTGGAGCACAACA-3' & \multirow{2}{*}{$\begin{array}{c}\text { Annealing } \mathrm{T}\left({ }^{\circ} \mathrm{C}\right) \\
56\end{array}$} \\
\hline Antisense & 5'-GCTGCTTAGTCATCTTCACAATC-3' & \\
\hline \multicolumn{3}{|c|}{ e } \\
\hline Sense & 5'-CGAGCAGATGGACCAAGAC-3' & \multirow{2}{*}{$\begin{array}{c}\text { Annealing } \mathrm{T}\left({ }^{\circ} \mathrm{C}\right) \\
56\end{array}$} \\
\hline Antisense & 5'AGGTAGAGTGGCCGTGCTC-3’' & \\
\hline \multicolumn{3}{|l|}{ M4 } \\
\hline Sense & 5'-TCCAATGAGTCCAGCTCAGG-3' & \multirow{2}{*}{$\begin{array}{c}\text { Annealing } \mathrm{T}\left({ }^{\circ} \mathrm{C}\right) \\
56\end{array}$} \\
\hline Antisense & 5-AGAGCATAGCAGGCAGGGTTG-3 ${ }^{\circ}$ & \\
\hline \multicolumn{3}{|l|}{ M5 } \\
\hline Sense & 5'-GGACTATAAGTTCCGATTGGTG-3' & \multirow{2}{*}{$\begin{array}{c}\text { Annealing } \mathrm{T}\left({ }^{\circ} \mathrm{C}\right) \\
56\end{array}$} \\
\hline Antisense & 5'-GGTGACTGGGACACACTTG-3' & \\
\hline \multicolumn{3}{|l|}{ MCP-1 } \\
\hline Sense & 5'-CAGCAGCAAGTGTCCCAAAG-3' & \multirow{2}{*}{$\begin{array}{l}\text { Annealing } \mathrm{T}\left({ }^{\circ} \mathrm{C}\right) \\
64\end{array}$} \\
\hline Antisense & 5'-GAGTGAGTGTTCAAGTCTTCGG-3' & \\
\hline \multicolumn{3}{|l|}{ 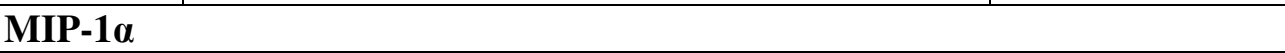 } \\
\hline Sense & 5'-TTCAGACTTCAGAAGGACAC-3' & \multirow{2}{*}{$\begin{array}{c}\text { Annealing } \mathrm{T}\left({ }^{\circ} \mathrm{C}\right) \\
62\end{array}$} \\
\hline Antisense & 5'-TGAGCAGGTGACGGAATG-3' & \\
\hline \multicolumn{3}{|l|}{ RANTES } \\
\hline Sense & 5'-TGCTGCTTTGCCTACATTGC-3' & \multirow{2}{*}{$\begin{array}{c}\text { Annealing } \mathrm{T}\left({ }^{\circ} \mathrm{C}\right) \\
64\end{array}$} \\
\hline Antisense & 5'-AAGACGACTGCTGGGTTGG-3' & \\
\hline \multicolumn{3}{|l|}{ GAPDH } \\
\hline Sense & 5'-TGATGACATCAAGAAGGTGGTGAAG-3' & \multirow{2}{*}{$\begin{array}{c}\text { Annealing } \mathrm{T}\left({ }^{\circ} \mathrm{C}\right) \\
62\end{array}$} \\
\hline Antisense & 5'-TCCTTGGAGGCCATGTAGGCCAT-3' & \\
\hline
\end{tabular}

Table 1. Primer sequences and annealing temperature. (M1-M5 primers were previously

publicated by Kylie J.Mansfield, British Journal of Pharmacology (2005) 144, 1089-1099)

This article is protected by copyright. All rights reserved. 